\title{
Response of Lychee (Litchi Chinensis) to layering media and timing factors under the climatic conditions of Haripur
}

\author{
Zahoor ul Haq ${ }^{1}$, Shah Masaud Khan ${ }^{1 *}$, Ijaz Hussain ${ }^{1}$, Sardar Ali ${ }^{1}$, Tariq \\ Mehmood $^{2}$, Ishrat Naz ${ }^{3}$, Muhammad Affan Khan ${ }^{1}$, Irshad Ahmad Khan ${ }^{4}$ \\ and Fazal e Haq Khan ${ }^{5}$ \\ 1. Department of Agricultural Sciences, the University of Haripur Khyber Pakhtunkhwa -Pakistan \\ 2. Fruit Nursery Farm Agriculture Extension Department Haripur-Pakistan \\ 3. Department of Plant pathology, University of Agriculture, Peshawar-Pakistan \\ 4. Department of Agriculture, University of Punjab, Lahore-PAkistan \\ 5. Department of Food Sciences, PMAS Arid Agri University Rawalpindi-Pakistan \\ *Corresponding author's email: shahmasaudkhan@gmail.com \\ Citation \\ Zahoor ul Haq, Shah Masaud Khan, Ijaz Hussain1, Sardar Ali, Tariq Mehmood, Ishrat Naz, Muhammad Affan \\ Khan, Irshad Ahmad Khan and Fazal e Haq Khan. Effect of different Media and Timing factors on rooting of \\ Lychee (Lychee chinensis) through air layering. Pure and Applied Biology. Vol. 6, Issue 4, pp1276-1282. \\ http://dx.doi.org/10.19045/bspab.2017.600136
}

Received: 04/05/2017 Revised: 15/09/2017

Accepted: 28/09/2017

Online First: 04/09/2017

\section{Abstract}

The study was conducted at the Fruit Nursery Farm Agriculture Extension Department, Haripur during 2013-14. To identify the most suitable time for layering in Lychee and to sort out the suitable growing medium for layering in Lychee at Haripur region. There were two factors Media (Sawdust, FYM, Silt and Garden Soil) and Time factors (10 June, 20 June, 10 July \& 20 July). The data was recorded on number of days to root appearance, number of root per layer, Root length $(\mathrm{cm})$, Root diameter $(\mathrm{cm})$ and rooting success $(\%)$. The results confirmed that all parameters were significantly affected by various media and timing factor. Maximum number of days to root appearance (62.58), roots per layer (37.25), root length $(9.43 \mathrm{~cm})$, root diameter $(0.25 \mathrm{~cm})$, layering success $(83.33 \%)$ was recorded in Silt media, while minimum number of roots per layer $(26.42)$, root length $(6.50 \mathrm{~cm})$ and layering success $(55.00 \%)$ was noted in Saw dust media while minimum days to root appearance (41.17), root diameter $(0.17 \mathrm{~cm})$ were recorded in FYM media. In case of timing factor maximum number of days to root appearance (65.75), number of roots per layer $(35.58)$, root length $(8.53 \mathrm{~cm})$, root diameter $(0.26 \mathrm{~cm})$ and layering success $(85.00 \%)$ was recorded in the air layering, which were made on $20^{\text {th }} \mathrm{July}$. The maximum number of days to root appearance (75.33), number of roots per layer (41.33), root length $(10.80 \mathrm{~cm})$, root diameter $(0.26 \mathrm{~cm})$ and layering success $(100.00 \%)$ was recorded in Silt media air layering made on $20 \mathrm{July}$. It was concluded that the best timing for air layering was $20^{\text {th }} \mathrm{July}$ and preferred media is silt media for Lychee propagation through air layering.

Keywords: Lychee (Lychee chinnensis); Air layering; Timing factors; Plant propagation

Introduction

Lychee (Litchi chinensis) belongs to family

Sapindaceae and its sub family Nepholeae. It is a sub-tropical, delicious, juicy fruit. It originated from Southern China particularly the provinces of Fukien Kwangtung. It is also 
called king of fruit in China. It is sowed and grown for over 3000 years and was introduced in India and Burma by the end of $17^{\text {th }}$ century [1].

Lychee is valuable because of their sugar content. The range of sugar content in different varieties is from 6.74 to $18.86 \%$ in India [2].

Beside sugar content in different cultivars ranges from 6.74 to 18.86 percent, besides sugar, Lychee contains $0.7 \%$ protein, $0.3 \%$ fat, $0.7 \%$ minerals (particularly calcium and phosphorus) and vitamin C 40-60 mg/100g pulp [3]

Lychee can be propagated both by sexual and asexual means but propagation by seed is not satisfactory because by this way varieties don't produce true to type plant and its seedling takes more than 6-12 years to come into bearing, while the propagation of Lychee through asexual means is not only capable to early bearing (2-3 years), but also produce new tree with fruits identical in color, taste, texture and maturity characters as parent plant [4].

Haripur District is one of the famous city of the Hazara Division in Pakistan. It is located $65 \mathrm{~km}$ north of Islamabad at an elevation of $520 \mathrm{~m}$. It has latitude $\left(33^{\circ} 44^{\prime}-34^{\circ} 22^{\prime}\right)$ and longitude $\left(72^{\circ} 35^{\prime}-73^{\circ} 15^{\prime}\right)$. Haripur is a green valley, rich in fruits and vegetables. Khanpur which is recognized for its red blood oranges and Lychee. There are four varieties of Lychee which are normally grown in Haripur namely China, Gola, Surahi and Bedana. Haripur has 1,294 acres of fruits orchards and Lychee orchards alone are spread over 100 acres [5].

In Lychee air layering is one of the most common and popular method for propagation in world wide. Air layering is the way to produce adventitious roots from the branch of an existing one while it is still attached to mother plant. Timing factor of air layering is most important factor for the success and survivability. Most of researchers observed that success of air layering mostly depend upon the timing of layering [6]

In Pakistan June and July is the best season for rooting and survival of air layering in Lychee. Rooting media is one of the most vital factors for suitable air layering. Sufficient porosity microbial activity and water holding capacity rooting media are the requirements of newly formed roots of the steam for healthy growth and penetration. The different rooting media of air layering are garden soil, saw dust, silt and FYM, among this media silt media is recommended for Lychee air layering [7].

\section{Objectives}

To identify the most suitable time for layering in Litchi, at Haripur region.

To sort out the suitable growing medium for layering in Litchi.

\section{Materials and methods}

\section{Experimental details and treatments}

The study titled "Response of Lychee to layering media and timing factors under the climatic conditions of Haripur" was conducted at the Fruit Nursery Farm Agriculture Extension Department, Haripur during 2013-14.

\section{Treatment layout}

Layering was done at different times and different media surrounded by the injured portion and then wrap with plastic sheet. In the experiment there were five (5) air layers in each treatment, twenty (20) air layers in each replication and sixty (60) air layers in each time period. The experiment was laid out in two factorial designs with three (3) replication and four (4) treatments.

The experimental design used for the study was Randomized Complete Block Design (RCBD) with two factors factorial arrangement.

\section{Factor A: Times of air layering}

The layering was done on following dates,

$$
\begin{aligned}
& \mathrm{T}_{1}=\text { June } 10 \\
& \mathrm{~T}_{2}=\text { June } 20 \\
& \mathrm{~T}_{3}=\text { July } 10
\end{aligned}
$$




$$
\mathrm{T}_{4}=\text { July } 20
$$

Factor B: Media

Different Medias were used to cover the injured portion i.e.

$\begin{array}{ccc}\text { Media } & \begin{array}{c}\text { Different } \\ \text { media }\end{array} & \begin{array}{c}\text { Composition of } \\ \text { Media }\end{array} \\ 1 & \text { Silt } & 100 \% \text { Silt media } \\ 2 & \text { FYM } & 90 \% \text { one year old } \\ & & \begin{array}{c}\text { FYM and } 10 \% \\ \text { garden soil }\end{array} \\ 3 & \text { Saw dust } & \begin{array}{c}90 \% \text { saw dust and } \\ 10 \% \text { garden soil }\end{array} \\ 4 & \text { Garden } & 100 \% \text { garden soil } \\ & \text { soil } & \end{array}$

\section{Parameters}

The fallowing parameters were studied during experiment.

\section{Number of days to root appearance}

The total number of days to root appearance was observed and average was recorded.

\section{Number of root per layer}

The soil attached with roots was removed by washing them in water and the number of root per layer branch was counted and the average was worked out.

\section{Root length (cm)}

Root length was measured from basal end to the tips of roots. The average was calculated after recording the roots measurement in each replication.

\section{Root diameter (cm)}

The cross sectional area of roots from selected treatment was noted with the help of Vernier caliper in centimeter and averages was recorded.

\section{Rooting success (\%)}

The rooting success (\%) was found out with the help of following formula.

Percent layer survival $=$

Total number of layer survival $\times 100$

$$
\text { Total number of layers }
$$

\section{Statistical analysis}

The data recorded on different parameters were subjected to the analysis of variance (ANOVA) technique to find out the difference between different treatments and there interaction. While difference among treatments mean were compared using LSD test $\mathrm{P} \leq 0.05$ collected data were statistically analyzed using computer software analysis of variance was used to the significant of variance[8].

\section{Results and discussion \\ Number of days to root appearance}

The mean value regarding days to root appearance in Lychee layering is given in Table 1 and Figure 1. The mean values of different soil media shows that maximum number of days to root appearance (62.58) was reported in Silt media significantly followed by Garden soil which take (58.50) days to root appearance. While minimum number of days (41.17) to root appearance was reported in FYM media significantly followed by Sawdust media which took (48.58) days to root appearance. Whereas the mean values of different air layering time shows that maximum days to root appearance (65.75) was observed in layer made on 20 July significantly followed by air layering made on 10 July which take (56.41) days to root appearance, while minimum number of days to root appearance (47.25) was recorded in layer made on 10 June significantly followed by air layering made on 20 June which take (51.41) days to root appearance. The effect of different medias and air layering timing factors showed that maximum number of days to root appearance (75.33) was reported in layer made on 20 July in Silt media followed significantly layer made on 20 July in Garden soil media which take (68.67) days to root appearance, whereas minimum days to root appearance (40.33) was reported in layer made on 10 June in Sawdust media followed by layer made on 10 June in FYM media which take (43.67) days to root appearance. The results are in line with [7] they reported the maximum days to roots appearance were obtained in silt media and minimum days to roots appearance were 
obtained in saw dust media. And maximum days to roots appearance were obtained in air layering made on 18 July. The maximum root appearance in June month is might be due highly availability of nutrients in Lychee plant. It might be the reason that the food materials in the shoot of Lychee is more in month of June as compared to July and it starts a new growth, there for they produce early rooting as compared to layer made on July [9].

\section{Number of root per layer}

The mean value of different media (given in Table 1 and Figure 2) shows that maximum number of roots per plant (37.25) was recorded Silt media significantly followed by Garden soil having (30.25) root per plant recorded, whereas minimum number of root per plant (26.42) was observed in Sawdust media significantly followed FYM media in which have (29.67) root per plant noted. While the mean values of different air layering time shows that maximum number of root plant- ${ }^{1}(35.58)$ was observed in layer made on 20 July significantly followed by air layering made on $10 \mathrm{July,} \mathrm{whereas} \mathrm{minimum}$ number of root plant $^{-1}$ (22.67) was recorded in air layering made on 10 July.

The effects of different media and air layering timing factors showed that maximum number of roots (41.33) was recorded in Silt media air layering made on 20 July followed by air layering made on 10 July and 20 June having (36.67) root per layer was recorded, whereas minimum number of root per air layer (22.67) was recorded in Sawdust media air layering made on 10 June followed by layer made on 10 June in Garden soil. The results are in line with [10]. The results are in argument with [7] they reported the maximum number of roots was obtained in silt media air layering made on July 18. While minimum number of root per air layering was noted in Saw dust Media. The maximum number of root per layer in Silt media layer made on 20 July is might be due to favorable temperature in month of July. The low rooting in Saw Dust media layer made on 10 June due high temperature. Which might enhance the respiration of the plant thus plant is lift with low net photosynthesis for rooting. The Silt media have more nutrients and provide ideal condition for the growth of roots [9].

\section{Root length (cm)}

The mean value of different media (Table 1 and Figure 3) shows that the maximum root length $(9.43 \mathrm{~cm})$ was recorded in Silt media followed significantly by Garden Soil in which $(7.68 \mathrm{~cm})$ root length was recorded, whereas minimum root length $(6.50 \mathrm{~cm})$ was recorded in Saw Dust media. While the mean value of different air layering times shows that maximum root length $(8.53 \mathrm{~cm})$ was noted in layer made on 20 July followed by $(8.48 \mathrm{~cm})$ root length of layer made on 10 July, whereas minimum root length $(6.71 \mathrm{~cm})$ was recorded in layer made on 10 June.

The effects of different media and air layering timing factors reflect that maximum root length $(10.80 \mathrm{~cm})$ was recorded in Silt media layer made on 20 July followed by air layering made on 10 July in Silt media, whereas minimum root length $(5.70 \mathrm{~cm})$ was recorded in Saw Dust media air layering made on 20 June. The results are in line with (Hossain et al., 2007) they concluded that success ratio of Lychee layer is more in month of July then other [9].

The results are in argument with [7]. They reported that maximum root length was obtained in Silt Media while minimum root length was obtained in Saw dust Media. The minimum root length in air layering made on 10 June in Saw Dust media could be due to high temperature in the month of June. In month of July temperature dropped the root length were increased it may be due to decrease in temperature because of less utilization of carbohydrate in respiration and extra energy would have been diverted to root development [7]. 


\section{Root Diameter $(\mathbf{c m})$}

The mean value of different soil media (Table 1 and Figure 4) showed that maximum root diameter $(0.25 \mathrm{~cm})$ was observed in silt media followed significantly Garden Soil media having $(0.19 \mathrm{~cm})$ root diameter, while minimum root diameter $(0.17 \mathrm{~cm})$ was recorded in farmyard manure followed by $(0.18 \mathrm{~cm})$ root diameter observed on Saw Dust. Whereas the mean values of different air layering times showed that maximum root diameter $(0.26 \mathrm{~cm})$ was noted in layer made on 20 July significantly followed by layer made on 10 July having $(0.26 \mathrm{~cm})$ root diameter, while minimum root diameter $(0.15$ $\mathrm{cm})$ was recorded in layer made on 10 June significantly followed by layer made on 20 June having $(0.18 \mathrm{~m})$ root diameter. The effects of different media and air layering timing factors showed that maximum root diameter $(0.34 \mathrm{~cm})$ was recorded in Silt media air layering made on 20 July. The minimum root diameter $(0.13 \mathrm{~cm})$ was noted in Saw Dust media air layering made on 10 June followed by FYM Media having (0.14 $\mathrm{cm})$ root diameter recorded in air layering made on 10 June. The maximum root diameter in Silt media on 20 July is may be due to high relative humidity from July 10 to up to September that might have compact transpiration which increased cell turgidity and improve cell division thus the better portion of available photosynthesis used in root development resulted in higher in root diameter. The results are in agreement with [7] they reported that air layering in Lychee is most successful during the month of July. They also confirmed that silt media is best for air layering in Lychee [7].

Table 1. Effect of different media and timing factors on rooting of Lychee (Lychee chinensis) through air layering

\begin{tabular}{|c|c|c|c|c|c|}
\hline \multicolumn{6}{|c|}{ Media } \\
\hline Media & $\begin{array}{l}\text { days to root } \\
\text { appearance }\end{array}$ & $\begin{array}{c}\text { Number of } \\
\text { root per layer }\end{array}$ & $\begin{array}{c}\text { Root } \\
\operatorname{length}(\mathrm{cm})\end{array}$ & $\begin{array}{c}\text { Root } \\
\text { diameter }(\mathrm{cm})\end{array}$ & $\begin{array}{c}\text { Rooting success } \\
(\%)\end{array}$ \\
\hline Saw Dust & $48.58 \mathrm{~d}$ & $26.42 \mathrm{c}$ & $6.50 \mathrm{c}$ & $0.18 \mathrm{c}$ & $55.00 \mathrm{~b}$ \\
\hline FYM & $41.17 \mathrm{c}$ & $29.67 b$ & $7.43 b$ & $0.17 \mathrm{c}$ & $61.67 b$ \\
\hline Silt & $62.58 \mathrm{a}$ & $37.25 b$ & $9.43 \mathrm{a}$ & $0.25 \mathrm{a}$ & $83.33 a$ \\
\hline Garden soil & $58.50 \mathrm{~b}$ & $30.25 a$ & $7.68 b$ & $0.19 \mathrm{~b}$ & $73.33 a$ \\
\hline LSD & 1.80 & 1.45 & 0.60 & 0.016 & N.S* \\
\hline \multicolumn{6}{|c|}{ Layering dates } \\
\hline $\begin{array}{l}\text { Layering } \\
\text { dates }\end{array}$ & $\begin{array}{l}\text { days to root } \\
\text { appearance }\end{array}$ & $\begin{array}{l}\text { Number of } \\
\text { root per layer }\end{array}$ & $\begin{array}{c}\text { Root } \\
\text { length }(\mathbf{c m})\end{array}$ & $\begin{array}{c}\text { Root } \\
\text { diameter }(\mathrm{cm})\end{array}$ & $\begin{array}{c}\text { Rooting success } \\
(\%)\end{array}$ \\
\hline 10 June & $47.25 d$ & $26.25 d$ & $6.71 \mathrm{c}$ & $0.15 d$ & $51.67 \mathrm{~b}$ \\
\hline 20 June & $51.41 \mathrm{c}$ & $29.50 \mathrm{c}$ & $7.43 b$ & $0.18 \mathrm{c}$ & $60.00 \mathrm{~b}$ \\
\hline 10 July & $56.41 b$ & $32.25 b$ & $8.48 \mathrm{a}$ & $0.21 b$ & $76.67 \mathrm{a}$ \\
\hline 20 July & $65.75 \mathrm{a}$ & $35.58 \mathrm{a}$ & $8.53 a$ & $0.26 a$ & $85.00 \mathrm{a}$ \\
\hline LSD & 1.80 & 1.45 & 0.60 & 0.016 & N.S* \\
\hline \multicolumn{6}{|c|}{ Media X layering dates } \\
\hline & $\begin{array}{l}\text { days to root } \\
\text { appearance }\end{array}$ & $\begin{array}{l}\text { Number of } \\
\text { root per layer }\end{array}$ & $\begin{array}{l}\text { Root } \\
\text { length }(\mathrm{cm})\end{array}$ & $\begin{array}{l}\text { Root } \\
\text { length }(\mathrm{cm})\end{array}$ & $\begin{array}{l}\text { Rooting success } \\
(\%)\end{array}$ \\
\hline & Fig:1 & Fig:2 & Fig:3 & Fig:4 & N.S* \\
\hline
\end{tabular}

Mean \pm standard deviation. Values sharing same letters differ non-significantly $(\mathrm{P}>0.05)$ 


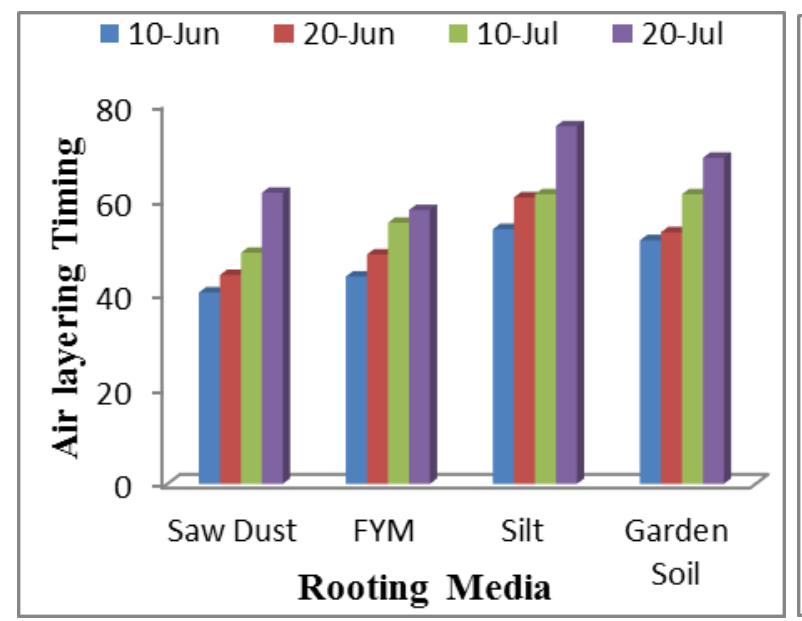

Figure 1.Effect of different Media and Timing factors on number of days to root appearance

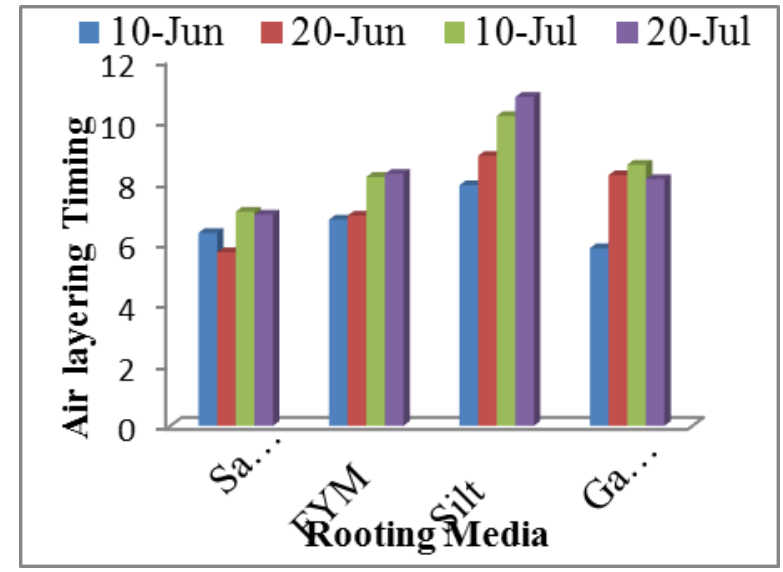

Figure 3. Effect of different media and timing factors on Root length $(\mathrm{cm})$

\section{Rooting success (\%)}

The mean value of different media showed that maximum rooting success $(83.33 \%)$ was recorded in layer made in Silt media followed by layer made Garden Soil having (73.33\%) rooting success $\%$, whereas minimum rooting success $(55.00 \%)$ was recorded in air layering made in Saw Dust media. While the Mean value of different air layering times shows that maximum rooting success $(85.00 \%)$ was noted in air layering made on 20 July followed by air layering made on 10 July having rooting success was (76.67\%),
ロ 10-Jun $\square$ 20-Jun $\square$ 10-Jul $\square$ 20-Jul

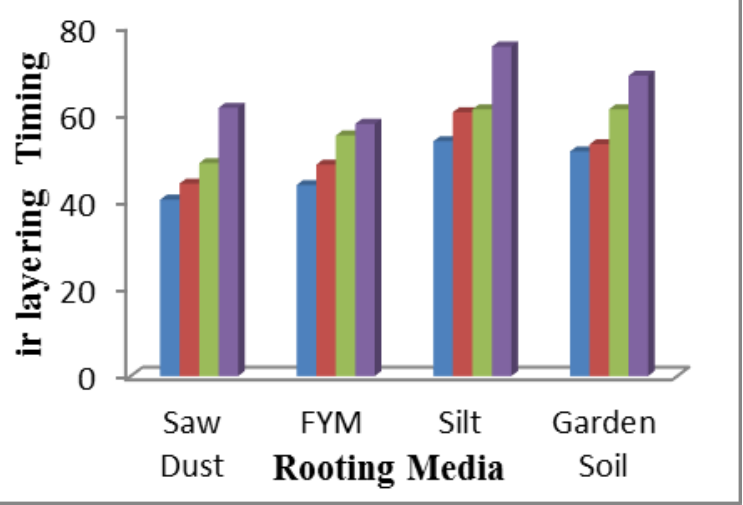

Figure 2. Effect of different media and timing factors on Number of root per air laver

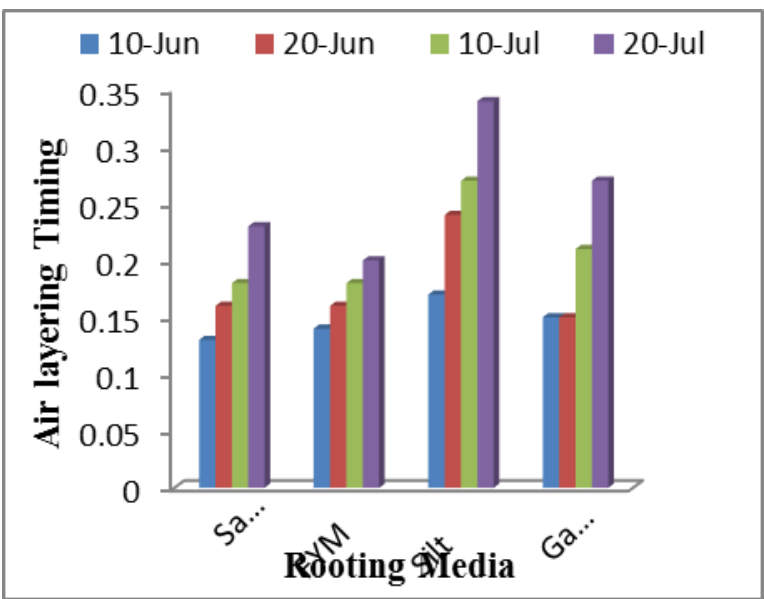

Figure 4. Effect of different media and timing factors on root diameter $(\mathrm{cm})$

whereas minimum rooting success $(51.67 \%)$ was noted in air layering made on 10 June. The maximum rooting success $(\%)$ in Silt media on 20 July is might be due to highly availability of Macro and Micro nutrients. While in month of July temperature dropped the root success (\%) were increased it may be due to decrease in temperature. The results are in agreement with [10] Maximum plant survival was recorded in the layers, which were made on 15 July [10]. 


\section{Conclusion}

The increase in success of Lychee air layering is depending upon the correct time and suitable media. So from this study it is concluded that among all soil Medias, Silt media was found most successful media, while in in timing factor 20 July was also superior.It is recommended in future research needs to be conducted on the response of different varieties of litchi to layering media. Authors' contributions

Conceived and designed the experiments: ZU Haq \& SMKhan, Performed the experiments: ZU Haq, T Mahmood \& S Ali, Analyzed the data:I Hussain \& MA Khan, Contributed materials/ analysis/ tools: SM Khan, I Naz \& IA Khan, Wrote the paper: ZU Haq \& SM Khan.

\section{References}

1. Liang, J (1981). The Lychee origin utilization and development of its culture. J of Agriculture Trinidad, 28(1): 259-270.

2. Sing. SN, Fazdar BS\& Sing M (1949). Effect of different time on rooting in jack fruit through air layering. Allahabag Fmr, 23(1): 93-97.

3. Hossain, $M$, Shahadat $H$ \&Islam $M$ (2014). Fruit setting, cracking and quality of Lychee (Litchi chinensis Sonn.) as influenced by foliar spray of different nutrient solutions during fruit growth and development. Journal of Agricultural Technology, 10(3):717-731.
4. Mee, W \& Folino JD (2003). Comments on Lychee propagation air layering and graft age Proceedings of the Florida State Horticultural Society. 4: 8-11.

5. Shahid, A, Anjum S, Muhammad A, Rafi\& Zia (2013). Insect pollinators of Lychee from district Haripur Pakistan. Pakistan Journal of Agricultural Research, 26(3): 112-115

6. Tomar, A (2016). Impact of seasonal changes on air layering and rooting hormone in Spondias Pinnata. Journal Koenig ex L. f. Kurz. Tropical Plant Research, 3(1): 131-135.

7. Awan, AA, Hussain I, Rehman N, Jan A \&Ali N (2000). Effect of different media and timing factor on rooting of Lychee plant trough air layering. Pakistan Journal Biological Sciences, 3(11): 1809-1810.

8. Steel, RGD, Torrie JH\& Boston MA (1997). Principles and Procedures of Statistics: A Biometric Approach. $3^{\text {rd }}$ ed. McGraue Hill Book Co. Inc. NY, 178-182.

9. Hossain, D., Choudhury, M.S., Hasan, M., Yeasmin, R. and Islam, A., 2007. Effect of shoot maturity and time of operation on Lychee air layering. Journal Agrofor Environ, 1(2). 193-197

10. Rehman, A, Awan AA, Owais, K\& Haq I (2013). Response of olive cultivars to air-layering at various timings. Pakistan J of Agriculture Sci, 50(4): 555-558. 